\title{
Organic Apple Systems: Constraints and Opportunities for Producers in Local and Global Markets: Introduction to the Colloquium
}

\author{
Kathleen Delate ${ }^{1}$ and Andrea McKern \\ Department of Horticulture, Iowa State University, 106 Horticulture Hall, Ames, IA 50011-1100 \\ Robert Turnbull \\ Department of Entomology, 110 Insectary Hall, Iowa State University, Ames, IA 50011-3140
}

James T.S. Walker, Richard Volz, Allan White, Vincent Bus, Dave Rogers, Lyn Cole, Natalie How, and Sarah Guernsey

The Horticulture and Food Research Institute of New Zealand, Ltd., Private Bag 1401, Havelock North, New Zealand Jason Johnston
The Horticulture and Food Research Institute of New Zealand, Ltd., Private Bag 92169, Auckland 1142, New Zealand

Additional index words. codling moth, fruit quality, nutrient uptake, scab-resistant cultivars

\begin{abstract}
The global market for total organic product sales was \$20 billion in 2005, continuing an annual growth rate of $20 \%$ to $35 \%$. In the United States, there were 937,000 ha of certified organic land in 2003 with 5626 ha of organic apples [Malus sylvestris (L.) Mill var. domestica (Borkh.) Mansf.]. Increases in organic fruit production have been associated with improved pest management methods, the use of disease-resistant cultivars, and organic-focused marketing schemes. Often constrained by lower apple yields and smaller fruit size compared with conventional counterparts, key challenges for organic growers include regulation of nutrient cycling processes to maintain crop yields while minimizing the need for external inputs. In local or regional organic markets, disease-resistant apple cultivars, such as 'Enterprise', 'Liberty', 'Redfree', and 'Gold Rush', have gained increased acceptance, whereas exporting countries have continued their use of cultivars susceptible to scab [Venturia inaequalis (Cooke)]. Integrated insect pest management approaches, including the use of kaolin clay, codling moth granulosis virus, and spinosad-based insecticides, have been successfully developed to comply with export standards and quarantines, and to meet market demand. Key pests, such as codling moth [Cydia pomonella (L.)], have been managed at damage levels less than $5 \%$ using these approaches. Future pest management strategies in organic apple production will focus on development of scab-resistant cultivars with enhanced storage capability and reduction in inputs associated with negative environmental and health effects.
\end{abstract}

Organic production has experienced rapid growth in the past 20 years, with organic apple production increasing fivefold in the last 6 years of the U.S. census (U.S. Department of Agriculture-Economic Research Service, 2003). Driving the increasing demand for organic products are consumer concerns regarding environmental health, food safety, and food quality (Crawshaw, 1997; Organic Trade Association, 2005). The objectives of this paper are 1) to evaluate the global outlook for organic apple production; 2) to review the current state of science on organic apple systems, including tree health and insect/disease management, particularly in humid regions where disease control is the most critical, and fruit quality comparisons in organic and conventional systems; and 3) to discuss future directions, including the development and use of scabresistant cultivars in humid regions.

\section{ORGANIC FRUIT PRODUCTION: THE GLOBAL PICTURE}

The global market for total sales of organic products is conservatively estimated

\footnotetext{
Mention of commercial brand names does not constitute an endorsement of any product by Iowa State University or cooperating agencies.

${ }^{1}$ To whom reprint requests should be addressed; e-mailkdelate@iastate.edu
}

at US\$20 billion, continuing an annual growth rate of 20 to $35 \%$ (Organic Trade Association, 2005). In the United States, there were 937,000 ha of certified organic land in 2003, of which 5626 ha were in organic apples, with the majority (3337 ha) in Washington state (U.S. Department of Agriculture-Economic Research Service, 2003). The more productive areas of the United States are the semiarid apple-producing regions, because of low disease pressure there (Granatstein, 2004). Organic apple research in the humid regions of the United States has taken a multifaceted approach to production systems, with new organic insecticides in Vermont (Garcia et al., 2004), scabresistant cultivars in Iowa (Delate et al., 2005) and New York (Merwin et al., 2005), and whole-orchard ecosystem dynamics, including rootstock selection, in Michigan (Whalon et al., 2005).

The European Union (EU) has also experienced tremendous growth in organic fruit production during the past 15 years, with nearly 4000 ha of fruit crops in the total 4.8 million ha under organic management (Willer and Richter, 2004). Support for organic production is greatest in the EU, where the 140,000 organic farms in member states are provided direct and indirect incentives to increase their organic acreage (Sayin et al., 2005). Organic fruit production areas in Switzerland, for example, increased fivefold in the 1990s as a result of new organic methods for pest and disease control, improved management and production practices, increased marketing incentives, and "green payments" for organic production by the EU (Weibel, 2001). Argentina and Chile are increasing their exports of organic apples to U.S. and E.U. markets, with 2000 ha of organic apples and pears in Argentina and 519 ha of organic apples in Chile (Sanchez, 2005). New Zealand is considered a world leader in organic apple production (McArtney and Walker, 2004), with $10 \%$ of all apple production certified as organic (2964 ha) (Statistics New Zealand, 2006). The growth of Integrated Fruit Production (IFP) programs, based on low-toxicity (nonorganophosphate) insecticide use has also increased, but IFP price premiums are not comparable with certified organic revenues (Campbell et al., 2006).

Organic fruit growers worldwide are confronted annually with key decisions regarding cultivar selection to meet production area constraints and market demands, insect pest and disease management, weed control, and plant nutrition (Weibel, 2001). In the first instance, organic standards prescribe that farmers should rely on traditionally developed (nongenetically modified), diseaseresistant fruit cultivars and should encourage the activity of beneficial insects for biological control of fruit crop pests (Ames and Kuepper, 
2004; U.S. Department of AgricultureAgriculture Marketing Service, 2006). When these options fail to provide adequate control, least toxic methods of pest management are used, such as naturally mined S and lime, or purchased, biologically based, pest management treatments (Swezey et al., 2000).

Because of these additional requirements, organic apple production is viewed as being labor intensive, but with fewer intermediate inputs per unit of output compared with conventional production (Mon and Holland, 2006). Higher price premiums and greater returns have been realized for organic apple systems in Switzerland (Weibel et al., 2004), in California (Swezey et al., 2000), and in Washington (Mon and Holland, 2006; Reganold et al., 2001). Reganold et al. (2001) determined that organic apple production was superior to integrated and conventional production in terms of both environmental and economic sustainability. In 2004, price premiums for organic apples had declined in Washington as a result of increased supply from greater numbers of organic-converted orchards (Peck et al., 2005), but prices stabilized in 2006. The profitability of organic apples was twice that of conventional counterparts in 2001 in New Zealand (Walker and McArtney, 2001). Increased demand for organic fruit in the EU has outpaced supply, with many EU states, such as Germany and the United Kingdom, becoming important markets for imported organic products (Sayin et al., 2005). In New Zealand, for example, organic apples exported to the EU in 2006 garnered a $41 \%$ premium price over conventional apples. This premium corresponds to the 30 to $40 \%$ higher-than-conventional price for organic apples in France (Dapena et al., 2005). In many developing countries, organic fruit production and exports are on the rise. Using Turkey as an example, researchers there believe that the development of a national organic program and cooperation among organic marketing organizations will further improve organic sales (Sayin et al., 2005). Many organic apple growers, particularly in humid regions, market their crop through local and regional retail outlets. These markets offer various premiums for organic apples, ranging from a 35\% premium price in New York (Merwin et al., 2005) to $100 \%$ in Iowa (Delate et al., 2005).

\section{ORGANIC APPLE CROP MANAGEMENT AND RELATIONSHIP TO TREE-SOIL NUTRITIONAL PARAMETERS}

Yield comparisons. Hughes et al. (2002) reported an average reduction in yield of $8 \%$ to $25 \%$ in New Zealand organic apple orchards compared with their conventional counterparts, depending upon the cultivar. Despite the proclivity for reduced yields in organic apple systems, Reganold et al. (2001) obtained equivalent yields in their organic, integrated (reduced use of least-toxic insecticides) and conventional 'Golden Delicious' apple systems. The organic system, relative to the other types, was more energy efficient, and produced sweeter apples and higher profits. In a continuation of this study with 'Gala' fruit, in 2002, organic yields were $66 \%$ and $50 \%$ that of conventional and integrated management respectively; but in 2003, organic yields were $33 \%$ greater than either of the other systems (Peck et al., 2006). Numerous researchers in the EU have also examined horticultural, environmental, and economic consequences of organic apple production. Roth et al. (2005) reported no differences in yields and quality among apples originating from organic and integrated production systems in Belgium. Decreased organic apple yields in Switzerland, however, are attributed to high disease and insect pressure on scabsusceptible cultivars in humid apple-growing regions (Tamm et al., 2004).

Individual fruit size and density, as well as fruit number, affects yield. Thus, fruit and flower thinning can affect fruit size and must be considered in organic systems. In many organic orchards $\leq 8$ ha in size, or where labor is plentiful, apple fruitlets are often thinned by hand, which may result in smaller fruit size when thinning is not adequate (Swezey et al., 2000). Compared with conventional and integrated apples, a smaller fruit in organic systems is also a commonly reported phenomenon, although there are exceptions. Wurm and Pieber (2005) did not obtain fruit size or density differences in organic or integrated 'Jonagold', 'Idared', and 'Topaz' apple cultivars in their study.

Different soaps, salts, and oils have been tested as organic apple thinners (McArtney, 2000 ), but $1 \%$ to $2 \%$ lime-S is currently the most effective, least phytotoxic, organiccompliant agent for thinning (Warlop, 2002). Some phytotoxicity from $S$ products may reduce tree growth and yield, however (McArtney, 2000). In years when organic apple supply is insufficient, hand thinning after spraying becomes economically advantageous, because the additional labor costs are offset by higher revenues (Hughes et al., 2002).

Soil quality effects on yield. Organic apple growers emphasize "soil health" and rely on slow-release $\mathrm{N}$ from high-C sources, such as manure, composted manure, and leguminous cover crops (Hughes et al., 2002). Other organic-compliant amendments, such as rock phosphate, and marine products (kelp, fish emulsion, and seaweed formulations) are commonly applied to the soil or in a foliar form in organic orchards. Trace minerals are often applied after soil and tissue tests determine a need for these restricted elements (U.S. Department of Agriculture-Agriculture Marketing Service, 2006). Commonly proposed theories to explain inconsistent organic apple yields include poor crop load management, low leaf tissue $\mathrm{N}$, and low fruit tissue $\mathrm{N}$ (Swezey et al., 1998). Hughes et al. (2002) suggested an association between poor tree performance and stress from sulfur-based products, overcropping, and nutrient imbalances or deficiencies, often resulting from an overestimate of $\mathrm{N}$ released from organic fertilizers. Recommendations specifically for organic orchards are under development. In the interim, growers rely on university/ research institute guidelines for conventional fruit trees, including maintaining leaf $\mathrm{N}$ levels of $1.8 \%$ to $2.8 \%$, depending upon cultivar and tree maturity (Stiles and Reid, 1991).

Investigations into the relationship between soil-tree nutrition and fruit sizeyield in organic systems have produced mixed results. Research on $\mathrm{N}$ and $\mathrm{C}$ cycling, including the influence of earthworms, and soil physical properties, such as bulk density, has predominated in these investigations. Berghman et al. (1999) determined an association between low yields in organic citrus and low $\mathrm{N}$ assimilation, although Dong and Shu (2004) reported high levels of foliar N (3\%) after manure applications of $15 \mathrm{t} \cdot \mathrm{ha}^{-1}$ in apple orchards in China, suggesting adequate assimilation. Weibel et al. (2005), however, found a $44.5 \%$ lower ratio of microbially bound $\mathrm{N}$ and $\mathrm{C}$ in organic settings compared with integrated apple systems. Werner (1997) reported no differences in organic and conventional soils in the respiratory ratio of biomass $\mathrm{C}$ to total organic $\mathrm{C}$, resulting from $\mathrm{C}$ inputs exceeding $\mathrm{C}$ losses via microbial respiration. Goh et al. (2000) found that $\mathrm{CO}_{2}$ evolution and microbial biomass $\mathrm{C}$ and $\mathrm{N}$ were more affected by soil depth versus management type. Lower soil bulk density, which decreases with increasing soil porosity; higher soil infiltration rates; and greater earthworm numbers were found in organic soils compared with conventional soils in this study, however. Glover et al. (2000) also determined reduced soil bulk density in organic orchards. Weibel et al. (2005) found increased earthworm biomass and biodiversity in pea straw-treated tree rows of organic sites compared with conventional orchards. Werner (1997) also reported that, during the third year of conversion to organic orchard management, earthworm abundance and biomass increased in organic soils compared with initial populations in the conventional soil, a trend also observed in organic orchards in California (Swezey et al., 1998) and in New Zealand (Daly, 1994). Alfalfa and clover inputs were associated with an enhancement of beneficial nematodes involved in nutrient cycling in organic orchards (Forge et al., 2003).

Regarding other nutrient differences, organic apple trees in the Werner (1997) study exhibited higher P levels, similar to California organic systems (Swezey et al., 1998), where there was an increased formation of mycorrhizal associations. Weibel et al. (2005) found that the P content of fruit was not correlated with the $\mathrm{P}$ soil content, however. These researchers did find greater levels of $\mathrm{K}$ and $\mathrm{S}$ in organic tree rows supplemented with pea straw compared with conventional counterparts. Goh et al. (2000) also found that the addition of mown clippings from tree alleyways in organic and integrated orchards increased overall nutrient levels in these areas. 
Overall improvements in soil biology in the integrated and organic orchard systems were reported by Glover et al. (2000) when soil quality indices were higher than the conventional system. Integrated management was found to enhance soil aggregate stability, microbial biomass, and earthworm numbers relative to conventional apple orchard management. Because of similar strategies in organic and integrated systems, Reganold et al. (2001) found that both these systems produced higher soil quality and lower potential adverse environmental impacts compared with the conventional apple system.

Pest effects on yield. Unmanaged weeds, insects, and disease decrease yield directly or by affecting nutrient availability. Weeds are managed through various methods in organic apple orchards, including mowing in tree rows and alleys, or using straw and bark mulches, with the primary goal of limiting nutrient and water competition between tree and understory crop/weed species (Hartley and Rathmen, 1998). Orchard understory species composition can be manipulated to promote plant species that support beneficial insects (Altieri and Schmidt, 1985; Daly, 1994; Rogers et al., 2003). A "Swiss Sandwich System" (Weibel et al., 2004) of orchard understory management that allows local vegetation in the tree row center $(60 \mathrm{~cm}$ wide) with tilled side strips ( $60 \mathrm{~cm}$ wide) has been adjusted in Michigan trials to address vigorous herbaceous growth in the tree rows (Zoppolo et al., 2003).

Mowing and sheep grazing of understory plants can also decrease host sites for leafrollers and other pests (Thomas and Burnip, 1994). Additional benefits from alfalfa- and paper-based mulches included mitigation of the root-feeding nematode Pratylenchus penetrans associated with apple replant disease (Neilsen et al., 2004). Mechanical weed control involving rotary tillage can eliminate weed competition but may also damage tree trunks and roots in certain instances (Wearing et al., 1995).

\section{ORGANIC FRUIT QUALITY COMPARISONS}

Consumers report a preference for organic foods, including fruits, on the basis of lower pesticide residues compared with conventional produce, although many consumers also select organic produce for perceived nutritional benefits (Organic Trade Association, 2005). Measurements of fruit quality are often inconsistent in organic and conventional comparisons, however, because of improper experimental design, such as comparing different cultivars within one site, or comparing identical cultivars from different sites. In a scientifically robust experiment of identical cultivars at the same site, Peck et al. (2006) found that organic apples had firmer flesh than conventional or integrated apples of similar size, and consumer panels rated organic and integrated apples as having higher quality than conventional apples. No differences were found among systems in soluble solids concentration, titratable acids, or the ratio of these two qualities.

Contrary to Peck et al. (2006), DeEll and Prange (1992) found that organic apples had higher soluble solids levels compared with conventional counterparts. Organic 'McIntosh' were firmer than conventional 'McIntosh' apples at harvest, but not after storage. In 1993, DeEll and Prange reported that marketable fruit losses during storage were lower for conventional apples compared with organic apples; the latter usually exhibited more storage rot, scab, and russeting, but similar levels of core browning to conventional fruit. Organic 'McIntosh' apples stored in ambient conditions for 8 months, a storage condition highly unlikely in commercial practice, exhibited the largest amount of senescent breakdown, and after 4 months showed higher amounts of splitting. On the other hand, conventional 'McIntosh' apples stored in controlled atmosphere (CA) showed the most internal browning after 8 months, and when stored in air, these fruit exhibited more scald than organic 'McIntosh'. Although production system did not affect $\mathrm{Ca}$ or $\mathrm{Mg}$ levels, organic apples were found to exhibit higher amounts of $\mathrm{P}$ and $\mathrm{K}$, and lower amounts of $\mathrm{N}$.

Wurm and Pieber (2005) also found that integrated production was more successful than organic at controlling bitter pit disorder, but there were no differences in juiciness, sweetness, tartness, off flavor, or titratable acids between production systems either at harvest or after storage. Weibel et al. (2005), however, found that apples from organic orchards exhibited firmer flesh and higher indices of fruit quality (sugars and malic acid content), P content, flavonol levels, and taste scores than integrated apples, with no differences in storability among apple types. The relationship between enhanced antioxidant production in organic fruit and the absence of pesticide protection has been explored in numerous studies. Peck et al. (2006) found organic apples contained higher levels of total antioxidant activity than apples from integrated and conventional systems.

\section{INSECT AND DISEASE MANAGEMENT IN ORGANIC FRUIT SYSTEMS}

Insect and disease management constitutes a daunting challenge for organic apple growers in humid regions. Because plant health is associated with pest tolerance (Altieri, 1995), crop management is an important consideration for all apple growers, but particularly in organic systems where synthetic fertilizers and insecticides are prohibited. The ecology of the orchard, including interactions among understory vegetation, arthropod populations, soil microbes, and tree growth and development, is key in organic systems (Whalon et al., 2005). A systems approach in regulating pest species is prescribed in the U.S. Department of Agriculture-National Organic Program (NOP) rules (U.S. Department of Agriculture-
Agriculture Marketing Service, 2006). Organic farmers rely on biological, cultural, and physical methods to limit pest expansion and to increase populations of beneficial insects on their farms. After the need for intervention is verified, organic growers can use naturally occurring materials, such as $\mathrm{S}$, and approved synthetics, recorded in a national list (U.S. Department of AgricultureAgriculture Marketing Service, 2006). As a result of this regulation, all inputs must be reviewed by independent third-party inspectors.

Insect pest management. Organic growers throughout the world use the principles of natural enemy conservation by providing food and nesting sources for beneficial insects in the orchard system via cultivation of suitable cover crops to sustain them (Solomon et al., 2000; Wratten and Thomas, 1990). Obtaining the ideal ratio of pests and beneficial insects has been the subject of research in Michigan organic orchards, where phytophagous and predatory mite species are used as indicator species (Nortman et al., 2005). Wyss (1996) found that aphid predators and alternative prey colonized the cover crop strip-managed area to a greater extent than control areas, despite similar predator and prey species composition in both areas. Samu et al. (1997), however, found that total number of spiders was not changed by additional vegetation in the herbaceous layer in integrated orchards. Flowers, rather than vegetation alone, may be required, as Wyss (1995) found that when the weeds were flowering, larger numbers of aphidophagous predators, including spiders, Heteroptera, Coccinellidae, and Chrysopidae, were found on apple trees planted in weed strips than in the control areas. Aphid pests Dysaphis plantaginea and Aphis pomi were more abundant in the control area than among the weed strips (Wyss, 1995). Reports of comparisons of beneficial soil-dwelling arthropods in organic and conventional orchards are limited, although Mäder et al. (2002) have reported greater populations of predaceous ground-dwelling beetles in organic grain crops compared with conventional systems. Enhancement of codling moth larvae mortality by predatory nematodes occurred through the addition of wood chips into tree rows (Lacey et al., 2006).

Codling moth is the most widely reported apple pest in both conventional and organic orchards. Dapena et al. (2005) reported that neem-based treatments were necessary only for codling moth and rosy apple aphid management, with all other pests under biological control. Codling moth is most often managed with a multiprong approach: mating disruption, which involves the dispersion of a pheromone from strips hung in trees to confuse the mating pattern of male moths, and applying other organically acceptable spray treatments (Suckling et al., 1994). Organic-compliant sprays include kaolin clay products (Friedrich et al., 2003; Garcia et al., 2004). Mating disruption pheromone technology is considered an essential component 
of codling moth management in organic apple orchards (Swezey et al., 2000; Walker, 2006) and involves the placement of pheromone dispensers, such as Isomate (Pacific Biocontrol Corp., Vancouver, WA) throughout the orchard at rates of 1000 dispensers/ha or more, depending on generation numbers of codling moth normally encountered in a season and orchard location. In addition, organic growers now routinely apply codling moth (Cydia pomonella) granulosis virus (CpGV) for codling moth control. Because the virus particles must be consumed by the larvae, products such as Madex (Key Industries, Ltd., Auckland, NZ) in Europe and New Zealand and Cyd-X (Certis USA, LLC, Columbia, MD) in the United States must be applied at strategic times to control the first larvae. By increasing the area where mating disruption and $\mathrm{CpGV}$ are used, a more effective codling moth management system occurs as a result of the creation of a zone of mating confusion and an epizootic environment (widespread codling moth disease). Bacillus thuringiensis Berliner (Bt), another natural stomach poison for lepidopteran larvae, is also used for codling moth and leafroller management. The combination of these tactics has resulted in codling moth infestation levels equal to or less than 5\% (Delate et al., 2005; Walker, 2006). However, orchard proximity to wooded areas containing wild apple, plum, or hawthorn species serving as refugia for key pests could negate effective pest management in some areas. Other pests, such as plum curculio beetles [Conotrachelus nenuphar (Herbst)] in the United States (Whalon, 2006) and bronze beetle (Eucolaspis brunnea) in New Zealand, may also migrate from neighboring areas and warrant additional controls (Rogers et al., 2006).

For exporting growers, compliance with the importing country's regulations against the potential or actual presence of insects not present in their country requires strict adherence to specific quarantine procedures (Neven, 2007). Low-temperature CAs (2\% $\mathrm{O}_{2}, 2 \% \mathrm{CO}_{2}$ ) at temperatures of $0.5^{\circ} \mathrm{C}$ for a minimum of 8 weeks have been used successfully for treating specific quarantined insect pests (Jamieson et al., 1999; Waddell et al., 1990); and recently, CATTS (Controlled Atmosphere Temperature Treatment System) technology, using moist or vapor forced hot air with a CA, has become available for apple disinfestation (Neven and Rehfield-Ray, 2006). These organic-compliant treatments may increase market access and allow a longer storage period for scab-resistant cultivars, currently a limitation of these cultivars.

Disease management. There is a general acceptance in the commercial organic apple industry that scab disease (called black spot in Europe and New Zealand) is the principal limiting factor in the production of organic apples in humid regions (Tamm et al., 2004). Other diseases, including powdery mildew (Podosphaera leucotricha) and fire blight (Erwinia amylovora), can also be problematic in certain years in organic orchards. In addition to causing lesions on apple leaves, scab can render the apple nonmarketable when infection results in multiple, scablike blemishes on the apple surface. Management protocols have included combinations of lime, $\mathrm{S}$, or $\mathrm{Cu}$ timed to match infection periods. Scab infection periods can range from very few in drought years to more than 10 episodes in warm, wet years like 2006. Sulfur and lime-S may be the only remaining options after EU regulations against $\mathrm{Cu}$ fungicides extend to other regions (Holb and Heijne, 2001). Nonchemical integrated approaches to scab management include the use of scab-resistant cultivars and sanitation techniques to destroy infected leaves and fruit on the orchard floor at the end of the season (Carrise and Dewdney, 2002). In New Zealand, sheep grazing in orchards in the winter can assist in scab management (Hughes et al., 2002). Pruning mildew- and Erwinia-infected shoots and limbs can assist in mitigating disease spread in orchards, but sprays are also applied, including a competitor biocontrol spray of $E$. herbicola against E. amylovora.

Sulfur products, although noncarcinogenic, can cause respiratory problems in humans and have been shown to decrease the photosynthetic capacity of the apple tree, particularly in 'Braeburn' apples. Partial scab control is also obtained with lime and lime-S products applied as fruit thinners in the spring. Although $\mathrm{Cu}$ is currently still in use in organic orchards for scab-susceptible cultivars, pressure is increasing from environmental groups to limit potentially toxic levels of S and $\mathrm{Cu}$ (Holb and Heijne, 2001; McCarthy, 1996). In addition, russeting, a cosmetic defect limiting apples for export, may also result from $\mathrm{Cu}$ applications (Beresford et al., 1995). Permitted fungicides for scab control in organic orchards may also be negatively affecting predatory mite populations (Nortman et al., 2005).

Scab-resistant cultivar development has been a consistent focus of U.S. apple breeders since the 1940s (Crosby et al., 1992). In humid regions, these cultivars represent the only practical method of commercially producing organic apples without fungicides (Ellis et al., 1998). Recently, breakdown of resistance to specific races of Venturia inaequalis (MacHardy, 1996) has increased efforts in breeding programs worldwide to develop cultivars with new monogenic and polygenic resistance to scab and other apple diseases (Bus et al., 2002; Fischer, 2000). In New Zealand, for example, breeding efforts include germplasm collection, evaluation and genetics, development of parents with multiple resistances, and commercial cultivar breeding (White and Bus, 1998). However, breeding for both scab resistance and export quality in apples may require up to five generations of selections (Bus and Gardiner, 1998). Selecting under field conditions meeting certified organic status is imperative for evaluating the utility of new cultivars for organic orchards (Weibel et al., 2003). Because of the potential for breakdown, and to limit the development of other apple diseases, an organic-compliant fungicide during the $V$. inaequalis ascospore release period is recommended even with scab-resistant cultivars (Bus, 1999).

\section{CONCLUSIONS AND FUTURE DIRECTIONS}

The steady increase in consumer demand for organic products during the past decade should be viewed as a promising opportunity for organic producers throughout the world. Organic producers' ability to compete in this market has been documented in the midwestern United States (Delate et al., 2005), in Washington (Reganold et al., 2001), and in the EU (Roth et al., 2005). However, growers in humid areas using scab-susceptible cultivars have reported lower yields (Weibel et al., 2004). Obtaining comparable apple size and yield from C-based amendments in organic orchards remains a major challenge. With the majority of studies reporting improved nutrient cycling in organic orchards, synchronization of nutrient additions and tree uptake remains a critical area of research for organic systems.

The reduction in toxic pesticides in IFP apple systems is heralded as a significant environmental benefit for growers and consumers alike. Integrated approaches have provided "stepping stones" for conventional growers interested in transitioning to organic production (Coombes et al., 1998). With all comparisons, integrated systems have consistently produced greater apple yields, but certain organic systems, particularly in semiarid regions or in humid areas with intensive scab management programs, have also produced excellent fruit yield and quality. Branding of integrated and organic fruits, such as the ZESPRI Green logo from New Zealand, has been instrumental in raising consumer awareness of sustainable horticultural practices (Campbell et al., 2006). Despite the inherent value of IFP fruit, however, significant premium prices currently exist only for products with the certified organic label. These premium prices for both local and exporting organic apple growers must be continued to meet production costs (Bertschinger et al., 2004).

The introduction and use of scab-resistant cultivars will greatly reduce the high production costs associated with intensive spray programs for apple scab management. Molecular marker-assisted selection has been included in many apple breeding programs to enhance the development of cultivars with durable scab resistance and acceptable fruit quality (Bus et al., 2002). In addition to disease management, insect pest management will continue to require innovative strategies for increasingly important pests. Current strategies for codling moth management have proved successful, but new pests and pests under quarantine, such as leafrollers in New Zealand, remain as challenges for organic growers exporting to the United States (Delate et al., 2007; McArtney and Walker, 
2004). The widespread use of new NOPcompliant insecticides will require an examination of their nontarget effects on predators and parasitic wasps to maintain biodiversity in organic orchards.

In conclusion, the management of key insects and diseases in organic apples for local and export markets has achieved a relatively high level of success as a result of intensive integrated programs involving cultural, biological, and organic-compliant chemical controls. In semiarid organic apple regions, management of weeds and soil fertility remain key research issues. Exporting apple growers in humid regions who grow scab-susceptible cultivars must use intensive spray programs to meet quarantine and market demands. The rapid turnover of organic apples in local markets currently offers growers a financial advantage for scabresistant cultivars with a short storage life. The future of a sustainable organic apple industry, however, is dependent on the development of organic-compliant pesticides with reduced nontarget effects and storage extension of new scab-resistant cultivars through genetic improvements or organic alternatives, including CA and temperature treatments for export markets.

\section{Literature Cited}

Altieri, M.A. 1995. Agroecology. Westview Press, Boulder, CO.

Altieri, M.A. and L.L. Schmidt. 1985. Cover crop manipulation in Northern California orchards and vineyards: Effects on arthropod communities. Biol. Agr. Hort. 3:1-24.

Ames, G.K. and G. Kuepper. 2004. Overview of organic fruit production. Appropriate Technology Transfer for Rural Areas. Fayetteville, Ark. 10 Oct. 2006. $<$ http://www.attra.ncat.org/attrapub/fruitover.html>.

Beresford, R., C.H. Wearing, J.T.S. Walker, M. Spink, R.R. Marshall, and V. White. 1995. Copper and slaked lime for control of black spot and powdery mildew in apples, p. 83-88. In: Proc. 48th New Zealand Plant Protection Conf.

Berghman, P., M. Crestey, G. de Monpezat, and P. de Monpezat. 1999. Citrus nitrogen nutrition within organic fertilization in Corsica, p. 211214. In: D. Anac and P. Martin-Prevel (eds.). Improved crop quality by nutrient management. Kluwer Academic Publishers, Dordrecht, The Netherlands.

Bertschinger, L., P. Mouron, E. Dolega, H. Höhn, E. Holliger, A. Husistein, A. Schmid, W. Siegfried, A. Widmer, M. Zürcher, and F. Weibel. 2004. Ecological apple production: A comparison of organic and integrated applegrowing. Acta Hort. 638:321-332.

Bus, V. 1999. Resistance management with black spot resistant apple cultivars. Technol. Update $1: 40-45$.

Bus, V. and S. Gardiner. 1998. Pest and disease resistance in apple: Sources of genetic resistance. Orchardist New Zealand 71:54-55.

Bus, V., A. White, S. Gardiner, R. Weskett, C. Ranatunga, A. Samy, M. Cook, and E. Rikkerink. 2002. An update on apple scab resistance breeding in New Zealand. Acta Hort. 595: 43-45.

Campbell, H., C. McLeod, and C. Rosin. 2006. Auditing sustainability: The impact of Eurep-
GAP in New Zealand, p. 157-173. In: G.C. Holt and M. Reed (eds.). Sociological perspectives of organic agriculture. CAB International, London, UK.

Carrise, O. and M. Dewdney. 2002. A review of non-fungicidal approaches for the control of apple scab. Phytoprotection 83:1-29.

Coombes, B., H. Campbell, and J. Fairweather. 1998. Recent developments in organic food production in New Zealand-Part 3: Exporting of organic produce from Gisborne district. Univ. of Otago, Dunedin, New Zealand.

Crawshaw, G. 1997. An overview of the organic industry in New Zealand. The New Zealand Plant Protection Society, Inc., Auckland, New Zealand.

Crosby, J.A., J. Janick, P.C. Pecknold, S.S. Korban, P.A. O'Conner, S.M. Reis, J. Goffreda, and A. Voordeckers. 1992. Breeding apples for scab resistance: 1945-1990. Acta Hort. 317:43-70.

Daly, M.J. 1994. Management techniques for organic apple production in Canterbury, New Zealand. The Horticulture and Food Research Institute of New Zealand, Ltd., Auckland, New Zealand.

Dapena, E., M. Minarro, and M.D. Blazquez. 2005. Organic cider-apple production in Asturias (NW Spain). Bulletin-OILB/SROP (International Organization for Biological and Integrated Control of Noxious Animals and Plants/ West Palaearctic Regional Section) 28:161-165.

DeEll, J.R. and R.K. Prange. 1992. Postharvest quality and sensory attributes of organically and conventionally grown apples. HortScience 27:1096-1099.

DeEll, J.R. and R.K. Prange. 1993. Postharvest physiological disorders, diseases and mineral concentrations of organically and conventionally grown McIntosh and Cortland apples. Can. J. Plant Sci. 73:223-230.

Delate, K., J. DeWitt, A. McKern, and R. Turnbull. 2005. Integrated approaches to organic pest management in the Midwestern U.S.A.: Case studies of three crops. Organic Research May 2005: 8N-15N. <organicresearch.com>.

Delate, K., J.T.S. Walker, R. Volz, J. Johnston, A White, V. Bus, R. Turnbull, D. Rogers, L. Cole, N. How, S. Guernsey, and A. McKern. 2008. Organic apple production in two humid regions: Comparing progress in pest management strategies in Iowa and New Zealand. HortScience 43:6-11.

Dong, S. and H. Shu. 2004. Sheep manure improves the nutrient retention capacity of apple orchard soils. Acta Hort. 638:151-155.

Ellis, M.A., D.C. Ferree, R.C. Funt, and L.V. Madden. 1998. Effects of an apple scab-resistant cultivar on use patterns of inorganic and organic fungicides and economics of disease control. Plant Dis. 82:428-433.

Fischer, C. 2000. Multiple resistant apple cultivars and consequences for apple breeding in the future. Acta Hort. 538:229-234.

Forge, T.A., E. Hogue, G. Neilsen, and D. Neilsen. 2003. Effects of organic mulches on soil microfauna in the root zone of apple: Implications for nutrient fluxes and functional diversity of the soil food web. Appl. Soil Ecol. 22:39-54.

Friedrich, H., K. Delate, P. Domoto, G. Nonnecke, and L. Wilson. 2003. Effect of organic pest management practices on apple productivity and apple food safety. Biol. Agr. Hort. 21:1-14.

Garcia, M.E., L.P. Berkett, and T. Bradshaw. 2004. First year results of the impact of a novel pest management technology on apple fruit quality. Acta Hort. 638:85-88.

Glover, J.D., J.P. Reganold, and P.K. Andrews. 2000. Systematic method for rating soil quality of conventional, organic, and integrated apple orchards in Washington State. Agr. Ecosystems Environ. 80:29-45.

Goh, K.M., D.R. Pearson, and M.J. Daly. 2000. Effects of apple orchard production systems on some important soil physical, chemical and biological quality parameters. Biol. Agr. Hort. 18:269-292.

Granatstein, D. 2004. Research directions for organic tree fruit production in North and South America. Acta Hort. 638:369-374.

Hartley, M.J. and A. Rathmen. 1998. Use of mulches and herbicides in an apple orchard. New Zealand Plant Protection 51:195-198.

Holb, I.J. and B. Heijne. 2001. Evaluating primary scab control in organic apple production. Gartenbauwissenschaft 66:254-261.

Hughes, J., H. Stiefel, and T. Fraser. 2002. Organic apple production. New Zealand pipfruit technical bulletin no. 004. Agr. New Zealand, Hastings, New Zealand.

Jamieson, L.E., B.C. Waddell, and P.G. Connolly. 1999. Low temperature treatment for control of quarantine pests: Quick reference guide. Report no. HR98P03.07. The Horticulture and Food Research Institute of New Zealand, Ltd., Auckland, New Zealand.

Lacey, L., D. Granatstein, S.P. Arthurs, H. Headrick, and R. Fritts, Jr. 2006. Use of entomopathogenic nematodes (Steinernematidae) in conjunction with mulches for control of overwintering codling moth (Lepidoptera: Tortricidae). J. Entomol. Sci. 41:107-119.

MacHardy, W.E. 1996. Apple scab, biology, epidemiology and management. APS Press, St. Paul, MN.

Mäder, P., A. Fließach, D. Dubois, L. Gunst, P. Fried, and U. Niggli. 2002. Soil fertility and biodiversity in organic farming. Science 296:1694-1697.

McArtney, S.J. 2000. Thinning options for organic apple production. Orchardist New Zealand 73:32-34.

McArtney, S.J. and J.T.S. Walker. 2004. Current situation and future challenges facing the production and marketing of organic fruit in Oceania. Acta Hort. 638:387-396.

McCarthy, T.P. 1996. Apple cultivars for use in organic pipfruit production systems. The Horticulture and Food Research Institute of New Zealand, Ltd., Auckland, New Zealand.

Merwin, I., G. Peck, and E. Vollmer. 2005. Organic orchards in the northeast: Progress, practices and problems, p. 61-62. In: D. Granatstein and A. Azarenko (eds.). Proc. Third National Organic Tree Fruit Res. Symposium. Washington State University Tree Fruit Research and Extension Center, Wenatchee, WA.

Mon, P.N. and D.W. Holland. 2006. Organic apple production in Washington State: An inputoutput analysis. Renewable Agr. Food Systems 21:134-141

Neilsen, G.H., D. Hogue, D. Neilsen, and T. Forge. 2004. Use of organic applications to increase productivity of high density apple orchards. Acta Hort. 638:347-356.

Neven, L.G. 2008. Organic quarantine treatments for tree fruits. HortScience 43:22-26.

Neven, L.G. and L.M. Rehfield-Ray. 2006. Confirmation and efficacy tests against codling moth, Cydia pomonella, and oriental fruit moth, Grapholitha molesta, in apples using combined heat and controlled atmosphere treatments. J. Econ. Entomol. 99:620-627.

Nortman, D., M.E. Whalon, and B.A. Croft. 2005. Mites in Michigan organic apple production, $\mathrm{p}$. 36-38. In: D. Granatstein and A. Azarenko (eds.). Proc. Third National Organic Tree Fruit 
Res. Symposium. Washington State University Tree Fruit Research and Extension Center, Wenatchee, WA.

Organic Trade Association. 2005. O.T.A. Newsletter. Organic Trade Association, Greenfield, MA.

Peck, G.M., P.K. Andrews, J.P. Reganold, and J.K. Fellman. 2006. Apple orchard productivity and fruit quality under organic, conventional, and integrated management. HortScience 41: 99-107.

Peck, G.M., P.K. Andrews, C. Richter, and J.P. Reganold. 2005. Internationalization of the organic fruit market: The case of Washington state's organic apple exports to the European Union. Renewable Agr. Food Systems 20: 101-112.

Reganold, J.P., J.D. Glover, P.K. Andrews, and H.R. Hinman. 2001. Sustainability of three apple production systems. Nature 410: 926-930.

Rogers, D.J., L.M. Cole, K.M. Delate, and J.T.S Walker. 2006. Managing bronze beetle, Eucolaspis brunnea, in organic apple orchards. New Zealand Plant Protection 59:1-6.

Rogers, D.J., J.T.S. Walker, I.C. Moen, F. Weibel, P.L. Lo, and L.M. Cole. 2003. Understorey influence on leafroller populations in Hawke's Bay organic apple orchards. New Zealand Plant Protection 56:168-173.

Roth, E., A.Z. Berna, K. Beullens, A. Schenk, J. Lammertyn, and B. Nicolai. 2005. Comparison of taste and aroma of integrated and organic apple fruit. Commun. Agr. Appl. Biol. Sci. 70:225-229.

Samu, F., V. Racz, C. Erdelyi, and K. Balazs. 1997. Spiders of the foliage and herbaceous layer of an IPM apple orchard in KecskemetSzarkas, Hungary. Biol. Agr. Hort. 5:131140 .

Sanchez, E.E. 2005. Organic fruit production in South America, p. 31-34. In: D. Granatstein and A. Azarenko (eds.). Proc. Third Natl. Organic Tree Fruit Res. Symp. Washington State Univ. Tree Fruit Res. and Ext. Ctr., Wenatchee, WA.

Sayin, C., R.G. Brumfield, M.N. Mencet, and B. Ozkan. 2005. The organic farming movement in Turkey. HortTechnology 15:864-871.

Solomon, M.G., J.V. Cross, J.D. Fitzgerald, C.A.M. Campbell, R.L. Jolly, R.W. Olszak, E. Niemczyk, and H. Vogt. 2000. Biocontrol of pests of apples and pears in northern and central Europe-3. Predators. Biocontrol Sci. Technol. 10:91-128.

Statistics New Zealand. 2006. Hectares of land certified as organic by region at 30 June 2002 . New Zealand. 10 Oct. 2006. <http://www. stats.govt.nz/tables/2002-ag-prod/organictables.htm>.

Stiles, W.C. and W.S. Reid. 1991. Orchard nutrition management. Information bulletin 219 . Cornell University Cooperative Extension, Ithaca, NY.

Suckling, D.M., G.M. Burnip, J.R. Clearwater, P.W. Shaw, G.F. McLaren, D. Thomson, and C.H. Wearing. 1994. Mating disruption for caterpillar control in organic pipfruit orchards in New Zealand. The Horticulture and Food
Research Institute of New Zealand, Ltd., Auckland, New Zealand.

Swezey, S.L., P. Vossen, J. Caprile, and W Bentley. 2000. Organic apple production manual. Publication 3403. University of California, Santa Cruz, CA.

Swezey, S.L., M.R. Werner, M. Buchanan, and J. Allison. 1998. Comparison of conventional and organic apple production systems during three years of conversion to organic management in coastal California. Amer. J. Alternative Agr. 13:164-184.

Tamm, L., A. Haseli, J.G. Fuchs, F.P. Weibel, and E. Wyss. 2004. Organic fruit production in humid climates of Europe: Bottlenecks and new approaches in disease and pest control. Acta Hort. 638:333-339.

Thomas, W.P. and G.M. Burnip. 1994. Pests and associated beneficials recorded in a Cantebury pipfruit orchard during the transition to "BioGro" certification. The Horticulture and Food Research Institute of New Zealand, Ltd., Auckland, New Zealand.

U.S. Department of Agriculture-Agriculture Marketing Service. 2006. National Organic Program. Final rule: 7 CFR part 205. USDA-AMS, Washington, DC. 10 Oct. 2006. <http://www. ams.usda.gov/nop $>$.

U.S. Department of Agriculture-Economic Research Service. 2003. Organic production in the U.S. USDA-ERS, Washington, DC. 10 Oct. 2006. <www.ers.usda.gov/data/ Organic/ $>$.

Waddell, B.C., P.R. Dentener, and T.A. Batchelor. 1990. Time-mortality response of leafrollers exposed to commercial controlled atmosphere coolstorage, p. 328-333. In: Proc. 43rd Weed and Pest Control Conf.

Walker, J.T.S. 2006. Organic apple benchmarking study update. The Horticulture and Food Research Institute of New Zealand, Ltd., Havelock North, New Zealand.

Walker, J.T.S. and S.J. McArtney. 2001. An economic assessment of organic apple production in Hawke's Bay orchards, p. 29-37. In D.M. Suckling and M.R. Butcher (eds.). Plant protection challenges in organic production. Proc. New Zealand Plant Protection Society Symposium, The New Zealand Plant Protection Society, Auckland, New Zealand.

Warlop, F. 2002. Regulation of fruit load in the apple tree in organic agriculture: Some thinners. Revue Suisse de Viticulture. Arboriculture Hort. 34:201-203.

Wearing, H., A. O’Brien, and R. Marshall. 1995. Biological fruit production. The Horticulture and Food Research Institute of New Zealand, Ltd., Auckland, New Zealand.

Weibel, F.P. 2001. Organic fruit production in Switzerland: Research and development to resolve cultural, management, and marketing problems. Amer. J. Alternative Agr. 16: 191-195.

Weibel, F.P., A. Haseli, O. Schmid, and H. Willer. 2004. Present status of organic fruit growing in Europe. Acta Hort. 638:375-385.

Weibel, F.P., A. Schmid, and A. Haseli. 2003. Efficient multi-location testing of scab resistant cultivars for organic apple production in Switzerland. Acta Hort. 622:335-342.

Weibel, F.P., D. Treutter, U. Graf, and A. Haseli. 2005. Sensory and health-related fruit quality of organic apples: A comparative field study over three years using conventional and holistic methods to assess fruit quality, p. 185-195. In: Proc. 11th international conference on cultivation technique and phytopathological problems in organic fruit growing, Weinsberg, Germany, 3-5 Feb. 2004.

Werner, M.R. 1997. Soil quality characteristics during conversion to organic orchard management. Appl. Soil Ecol. 5:151-167.

Whalon, M. 2006. Biopesticides for plum curculio control. Upper Midwest Organic Tree Fruit Network Newsletter 2:1-9.

Whalon, M., J. Flore, J. Biernbaum, G. Bird, R. Perry, J. Scrimger, B. Behe, P. Schwallier, G. Skeltis, L. Gut, S. Smalley, R. Hammerschmidt, G. Sundin, R. Zoppolo, D. Steffanelli, B. Wingerd, M. Solomon-Jost, D. Nortman, R. Harwood, G. Byler, D. Ruwersma, A. IrishBrown, J. Smeenk, D. Mutch, T. Dekryger, and B. Gore. 2005. Apple orchard ecosystem management: The organic apple project at the Clarksville, Michigan, horticultural experiment station, p. 35. In: D. Granatstein and A. Azarenko (eds.). Proc. Third National Organic Tree Fruit Res. Symposium. Washington State University Tree Fruit Research and Extension Center, Wenatchee, WA.

White, A.G. and V.G. Bus. 1998. Breeding commercial apple cultivars in New Zealand with resistances to pests and diseases. Acta Hort. 484:157-162.

Willer, H. and T. Richter. 2004. The world of organic agriculture, statistics and emerging trends in 2004. 10 Oct. 2006. <http://www. soel.de/oekolandbau/weltweit.html $>$.

Wratten, S.D. and M.B. Thomas. 1990. Environmental manipulation for the encouragement of natural enemies of pests, p. 87-92. In: R.J. Unwin (ed.). Crop protection in organic and low-input agriculture: Options for reducing agrochemical usage. British Crop Protection Council, Farnham, Surrey, UK.

Wurm, L. and K. Pieber. 2005. Performance test of different apple cultivars in organic and integrated production taking into account different management methods of tree rows. Part 2: Outer fruit quality. Mitt. Klosterneuburg Rebe Wein Obstb. Fruchteverwert. 55:38-56.

Wyss, E. 1995. The effects of weed strips on aphids and aphidophageous predators in an apple orchard. Entomol. Expert. Applicata 75:43-49.

Wyss, E. 1996. The effects of artificial weed strips on diversity and abundance of the arthropod fauna in a Swiss experimental apple orchard. Agr. Ecosystems Environ. 60:47-59.

Zoppolo, R., D. Steffanelli, and R. Perry. 2003. Ground floor management and rootstock selection for organic apple production. Michigan State University, East Lansing, MI. 10 Jan. 2007. <http://www.newenglandvfc.org/ sessions 03/organic apple production/groundfloor management rootstock selection organic apple prod.pdf $>$. 